Abstracta Iranica Abstracta Iranica

Revue bibliographique pour le domaine irano-aryen

Volume 31 | 2011

Comptes rendus des publications de 2008

\title{
"Some Parthian Queens in Greek and Babylonian Documents ». Iranica Antiqua, XLIII, 2008, p.
} 235-274.

\section{Vito Messina}

\section{(2) OpenEdition Journals}

Édition électronique

URL : http://journals.openedition.org/abstractairanica/39466

DOI : 10.4000/abstractairanica.39466

ISSN : 1961-960X

Éditeur :

CNRS (UMR 7528 Mondes iraniens et indiens), Éditions de l'IFRI

\section{Édition imprimée}

Date de publication : 15 mai 2011

ISSN : 0240-8910

Référence électronique

Vito Messina, « "Some Parthian Queens in Greek and Babylonian Documents ». Iranica Antiqua, XLIII, 2008, p. 235-274. », Abstracta Iranica [En ligne], Volume 31 | 2011, document 76, mis en ligne le 15 février 2012, consulté le 04 octobre 2020. URL : http://journals.openedition.org/abstractairanica/ 39466 ; DOI : https://doi.org/10.4000/abstractairanica.39466

Ce document a été généré automatiquement le 4 octobre 2020.

Tous droits réservés 


\title{
«Some Parthian Queens in Greek and Babylonian Documents ». Iranica Antiqua, XLIII, 2008, p. 235-274.
}

\author{
Vito Messina
}

1 The dating formulae expressed in two Greek parchments and in a number of cuneiform tablets from Babylonia refer to a group of 14 Parthian queens of the 2nd-1st century BC otherwise unknown in the documentary sources collected so far. The role played by these figures in the context of the Parthian court is still unclear, even when compared to that of the Seleucid queens that preceded them, because Greek and Roman historians do not provide extensive information and because, as far as we know, only the retinue of the early Arsacid sovereigns actually assimilated the habits of a Hellenistic court.

2 The study of the very few documents referring to the Parthian queens is then of particular significance for it can be an important contribution to our knowledge of the Parthian kingship. In this article these documents are considered together, in an historical view that allows to a general interpretation of the sparse evidences, particularly focusing on the titles of these queens, both in Greek and in cuneiform, and pointing to the connexion existing between their titles and their status.

3 Indeed, the references to the Seleucid queens seem to stress the importance of the royal family as a group, the queen and the sons of the king playing an important role within the court and the state.

4 Following these lines, the Author postulates that, in contrast, the documents of the Parthian period attest the disappearance of the royal family as a group, the Arsacid regime particularly stressing the unfettered power of the king solely. 
INDEX

Thèmes : 3.2.3. Séleucides, Parthes et Sassanides

\section{AUTEURS}

VITO MESSINA

Università di Torino 